\title{
The Vase of Ambrosia
}

\section{A Scriptural Cycle about the Black Death in Tibet}

\author{
William A. McGrath | ORCID: 0000-0001-9573-6640 \\ Department of Religious Studies, New York University, New York, NY, USA \\ wmcgrath@nyu.edu
}

\begin{abstract}
This is an introduction to and translation of the Vase of the Deathless Ones' Ambrosia Tantra. The Vase of Ambrosia presents itself as a treasure text that was taught by Padmasambhava in eighth-century Tibet and finally revealed five hundred years later. In the opening chapter, Padmasambhava explains that a devastating epidemic disease will spread to Tibet and ultimately kill three out of every four people in the world. Despite this dire prognosis, he also explains the medical and spiritual causes of the disease, such that the physicians and ritual specialists of the future will be able to treat their patients and protect themselves. Taken together, the Vase of Ambrosia is a scriptural cycle that represents the Tibetan experiences of and responses to the bubonic plague in the thirteenth century, and which continues to inspire Buddhist approaches to epidemic disease even today.
\end{abstract}

\section{Keywords}

Tibet - medicine - Buddhism - epidemic disease - bubonic plague - Black Death

\section{Introduction to the Vase of Ambrosia}

The Vase of Ambrosia is a cycle of scriptural revelations about a devastating epidemic disease in Tibet. Like countless other treasure texts, the work begins with an eighth-century conversation between Padmasambhava and his Tibetan wife, Kharchenza Yeshé Tsogyel. ${ }^{1}$ Kharchenza imagines a future period

1 On Yeshé Tsogyel in Tibetan history, see Gyatso 20o6; Liang 2020. 
of degeneration when the blessings of Padmasambhava have faded and unenlightened divinities again threaten the Buddhist order. She asks the Central Asian Master, who had recently subdued the restless demons of Tibet, ${ }^{2}$ to give instructions for the wretched beings that will have to face epidemic diseases hundreds of years in the future. Padmasambhava agrees, and the end result is the Vase of Ambrosia, a medical scripture on the diagnosis of, treatment for, and protection from epidemic disease, hidden as a treasure text for the sake of future generations.

Tibetan physicians and ritual specialists began transmitting the Vase of Ambrosia cycle as early as the thirteenth century. ${ }^{3}$ A passage from the text confirms this time of revelation:

In five hundred years, during the age of degeneration ... a body will awaken from the depths of the ocean and reverberate through the sky. It will shoot a poison arrow of miasma and awaken the eight classes of gods and demons. Thus, will begin an era of war, famine, and disease. ${ }^{4}$

References to the Vase of Ambrosia also first appear in the commentarial literature of the thirteenth century, five hundred years after the legendary life of Padmasambhava. One early survey of Tibetan medical literature lists the Vase of Ambrosia among other historical and mythical tantras, ${ }^{5}$ for example, while also retelling the myth that inspired this title. Although the eponymous vase

2 For the legend of Padmasambhava subduing the demons of Tibet, see Wangdu and Diemberger 2000. On its implications for epidemic disease in Tibet, see McGrath 2020.

3 The Vase of Ambrosia was transmitted in a manuscript (and probably oral) tradition for approximately five hundred years before it was published as part of the Great Treasury of Precious Revelations (rin chen gter mdzod chen mo) by Jamgön Kongtrul Lodrö Tayé ('jam mgon kong sprul blo gros mtha' yas, 1813-99) and Jamyang Khyentsé Wangpo ('jam dbyangs mkhyen brtse'i dbang po, 182O-92). On this traditional history, as well as a preliminary analysis of other themes in the work, see Simioli 2019.

4 Unless otherwise stated, translations are my own. This passage is from the Union of the Sun and Moon:Root Tantra (nyizla kha sbyor kyi rtsa rgyud) in the Vase of Ambrosia cycle, which is not included in the translation below. For this passage, see BDRC1, 2a; BDRC2, 8b; RCTD, 458 (f. $7 \mathrm{~b}$ ); ARR, 10 (abbreviations cited in note 24 below). The term that I translate as "miasma" literally means "breath" or "oral vapor" (kha rlangs). It comes from the mouths of spirits and demons and is often described as poisonous or pathogenic: "poison arrow of miasma" (dug mda' kha rlangs), "poisonous miasma" (gdug pa can gyi kha rlangs), "pathogenic miasma" (nad kyi kha rlangs), and "miasma of malicious spirits and demons" ('dre srin ma rung ba'i kha brlangs).

5 This is a reference to the Flight of the Great Garuda (khyung chen lding ba) in the Eighteen Additional Branches (cha lag bco brgyad) collection. See, for example, A ru ra 2005, 15. 
of ambrosia could refer to a vase held by the Buddha, Master of Medicine, ${ }^{6}$ the aforementioned "body" awakening "from the depths" is a subtle but explicit reference to the famous "Churning the Ocean of Milk." In the Tibetan telling of this myth, the gods and demons cooperate to churn the primordial ocean of milk, thereby producing both a quintessentially poisonous being and the ambrosia of immortality. The gods subdue the monster, causing its dissolution into the poisonous plants and animals of the world, and finally retrieve the vase of ambrosia from the demons. ${ }^{8}$ Thus, the full title of the text translated below, the Vase of the Deathless Ones' Ambrosia, refers to the primordial panacea that both sustains the gods and dispels the diseases of this world.

The thirteenth century was an era of war, disease, and presumably famine in certain areas of Tibet. In the 1220 s the budding Mongol empire (ca. 1200-1350) conquered its southern neighbor and the patron state of Tibetan Buddhist lineages,${ }^{9}$ the Tangut kingdom of Xixia $(1038-1227) \cdot{ }^{10}$ Ögödei Khagan (11861241) then stationed his son, Prince Köden (1206-51?), in Liangzhou 涼州 (byang ngos), at the northeastern extreme of the Tibetan plateau. In 1240 Prince Köden sent a military detachment to Central Tibet, resulting in hundreds of deaths and the destruction of at least two monasteries near Lhasa. ${ }^{11}$ Mongol armies marched on Tibet again in 129o, defeating the Drigung army, executing their political leaders, razing Drigung monastery, and quelling resistance to Mongol-Sakya hegemony in the eastern part of Central Tibet. ${ }^{12}$ Rather than renounce invading Mongols (hor, lit. "Uyghurs"; or sog po, lit. "Sogdians"), however, the Vase of Ambrosia explicitly refers to the armies of the Turks ( $t u$ ru ka) coming from the periphery to the center of Tibet (chap. 1). Thus, while the precise military context of the Vase of Ambrosia remains ambiguous, this brief mention of Turkic invaders probably refers to the fallout of the Mongol expeditions into Tibet between 1240 and $1290,{ }^{13}$ and the related conflicts between the

$6 \quad$ See the "begging bowl filled with nectar which cures diseases, restores the dead to life and prevents aging" in the left hand of the Buddha, Master of Medicine (sangs rgyas sman bla = Skt. bhaișajyaguru) in the first plate of Parfionovitch, Meyer, and Dorje 1992, 17-18.

7 For this myth in South Asian tradition, see, for example, Doniger 1975, 270-300.

8 See my translation of this myth as told in the Flight of the Great Garuda in McGrath 2017a.

9 On the early, and still inadequately understood, relationships between Tibetan adepts and their Tangut patrons, see Sperling 1987a, 2004.

10 See, for example, Dunnel 1994.

11 Wylie 1977; Petech 1990, 7.

12 Sperling 1987a; Petech 1990, 30-31.

13 The explanation that, "Within the span of sixty years, [long enough for] one's teeth to fall out, the heartless and murderous soldiers of peripheral peoples will seize this central country" (chap. 5), supports the hypothesis that the early layers of the Vase of Ambrosia were composed leading up to and during the 129os. This statement would then represent 
East Asian Yuan dynasty and the Central Asian Chagatai khanate in the latter half of the thirteenth century. ${ }^{14}$ The violence of the expanding Mongol empire is an old story, but historians are now beginning to tell the tale of an epidemic disease that ravaged the pan-Eurasian Mongol empire during its apogee in the thirteenth and fourteenth centuries. ${ }^{15}$

The diagnostic instructions of the Vase of Ambrosia are at times specific enough to represent a single disease (chap. 8), but also can be general enough to apply to all epidemic and contagious diseases (rims nad). In line with the findings of recent studies on the global history of the Black Death, the Vase of Ambrosia is best understood as an account of the bubonic plague in thirteenth-century Tibet. There are descriptions of aching bodies (chap. 2), unusual bruising (chap. 3), skin "folds" (chap. 6), and "lumps" (chap. 9.1.3) at the patient's legs, waist, crotch, upper torso, and neck, for example, which suggest the horrific necrosis and characteristic swellings of the bubonic plague. ${ }^{16}$ Tellingly, the work also states that three of every four people on earth will die of this disease (chap. 1). Padmasambhava explains that the "names for this illness are inexhaustible" (chap. 4), but the most common names are the "Black Collapse" (nag po rgyug 'gyel), the "Black Triad" (nag po sum sgril), or some combination of the two. ${ }^{17}$ Padmasambhava attributes the disease to a host of existential and ethical factors before explaining the etiological framework at the core of the text: nyen spirits, heat disease, and wind disease (chap. 4 and chap. 9). He also states that the disease might manifest in different parts of the patient's body, which are usually expressed in terms of the organs and the elements. This combination of diverse anatomical and elemental symptoms provides a myriad of potential diagnoses and treatments that the physician can use in accordance with the specific contexts of a patient.

Pairing observable symptoms with the elements allows physicians to prescribe medicinal compounds based on the inference of elemental disorders. In the section on medicinal compounds (chap. 9), for example, the physician is

over fifty years of fear, resentment, and ultimately violent resistance to Mongol hegemony in the Drigung region. I plan to further explore this hypothesis in future publications.

14 Rossabi 1994. Also relevant is the invitation of Central Asian armies from the Chagatai khanate (stod hor) during the Drigung uprising of 129o. See Wylie 1977, 131; Sperling 1987b, 36; Petech 1990, 30-31.

15 Most recently, see Green 2020. Also Green 2014; Hymes 2014.

16 For a full review of the bubonic plague and its symptoms, see Benedictow 2010, 312-80.

17 One will not find these terms in the more orthodox works of Tibetan medical scholasticism, indicating the vernacular nature of this particular diagnosis. For a brief survey of epidemic diseases in the Four Tantras (rgyud bzhi), the Essence of the Eight Branches (yan lag brgyad pa'i snying po'i bsdus pa = Skt. așțāngahrdayasaṃhita), and other related texts, see Yang Ga 2010, 196-99. 
instructed to combine different plant, animal, and mineral ingredients based on the elemental characteristics and other symptoms of the patient. Although these same pentads of elements and viscera appear throughout Tibetan medical literature, ${ }^{18}$ here we find an inconsistent pairing of the usually four "great elements" ('byung $b a=$ Skt. mahäbhüta) of South Asian inspiration with the five interior viscera and usually six exterior organs (don lnga snod drug $=$ Chi. wuzang liufu 五藏六腑) of East Asian inspiration..$^{19}$ The Vase of Ambrosia also uses the archaic language of "inhabited valleys" (gnas pa'i yul), "haunted castles" ('khras pa'i rdzong), "pathways of wandering" ('phrang la 'grims), and "gateways of entry" ('jug pa'i sgo) for the patient's anatomy (chap. 8), giving the sense that the disease enters the patient's orifices from the outside, travels along their sensory channels, and occupies their internal organs, much like the aforementioned wars of conquest that took place throughout Eurasia in the thirteenth century. Building on this metaphor, we also find ritual "champions" (gyad) that will protect the gateways and medicinal "scouts" (zu gu [pa]) that will attack pathogenic enemies from the inside (chap. 7.2). The end result is an etiological system of both elemental imbalances and spiritual contagions, mediated by the movement of the winds in the channels and encapsulated by the threefold structure of the Black Triad.

Despite the aforementioned references to an elemental system of allopathic medicine that can be found across all cosmopolitan medical traditions of thirteenth-century Eurasia, the core intervention of the Vase of Ambrosia is ritual protection (chap. 7). Appealing to the classic formula of "inner, outer, and secret" categories, the root tantra advises inner protections of virtuous behavior, outer protections of medicines and amulets, and secret protections of tantric ritual and meditation. The Adamantine Armor of Meteoric Iron expands these latter instructions, emphasizing the importance of ritual protection with a simile: "Healing without bodily protection is like entering battle without armor."20 From beginning to end, the most important protection in the Vase of Ambrosia is the generation of divine pride, in which the physician dissolves

18 See, for example, McGrath 2o17b.

19 Various sets of four, five, or six "great elements" appear in the Vase of Ambrosia: earth, fire, water, wind, space, and consciousness. The five interior viscera are called "castles": liver, heart, spleen, lungs, and kidneys. Five of the six exterior organs are called "valleys": gallbladder, intestines, stomach, colon, and urinary bladder. The latter set excludes what is usually a sixth exterior organ, the polysemous samseu (sam se'u), which refers to the reproductive organs in Tibetan tradition, and the digestive “Triple Burner" (sanjiao 三焦) in Chinese tradition. For an analysis of the samseu as a gonad, see Gyatso 2015, 288-89.

20 This passage from the Adamantine Armor of Meteoric Iron (gnam lcags rdo rje'i khrab ring) is not included in the translation below. For this passage, see BDRC1, $27 b$ (mislabeled as 25b); BDRC2, 23a; RCTD, 476 (16b); ARR, 29. 


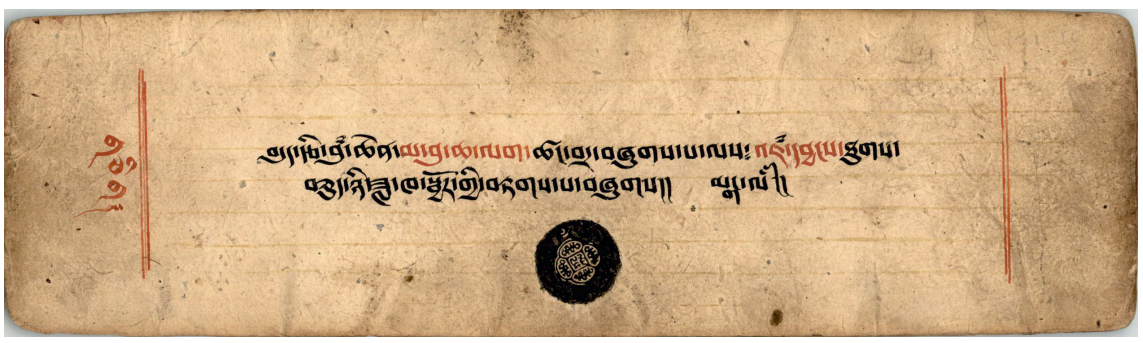

FIGURE 1 Folio 1a of the BDRC1 manuscript, once held at Pelpung monastery and marked with the seal of an official "physician" (lha rje; lit. "lord of the gods"): "The complete Great Vase of Ambrosia, including the mother, children, and additional branches ..." This image was scanned by BDRC and is now in the public domain.

his or her own sense of self into emptiness and reemerges as a blue Garuda. This bird spirit is famous for conquering the serpent spirit, the Nāga, as well as its associated poisons and diseases. ${ }^{21}$ Protected by the blessings of the Garuda and Padmasambhava, one can then proceed to cherish and treat "the young, the old, the infirm, and the abandoned like they are one's own heart" (chap. 9). Here the Vase of Ambrosia instructs physicians to heal their patients with the bodhisattva's altruistic aspiration for enlightenment, combined with the ritual protections of spells and divine pride. More than an idealistic plea, the Vase of Ambrosia is a consummate plan for compassionate care in an age of degeneration - an age characterized by violence, chaos, and the horrors of the Black Collapse.

Below is a translation of just the root tantra in the Vase of Ambrosia cycle. It contains ten chapters, which outline the narrative framework and practical instructions for the entire tantric cycle. Depending on the edition, the Vase of Ambrosia contains over thirty distinct textual sections, some of which include further clusters of chapters, sub-tantras, and other explanatory literature. At the core of the cycle is the root tantra (Fig. 1: "mother"; translated below), and three explanatory tantras ("children"): the Union of the Sun and Moon and the Sun Disc Illuminating Examination on diagnostics (which expand upon chap. 8 in the root tantra translated below), the Lamp Illuminating Practices on medicinal formulae for medical healing (root tantra, chap. 9), and the Adamantine Armor of Protection on ritual and meditative techniques for protection from epidemic disease (root tantra, chap. 7). The "additional branches" are further elaborations on diagnostics, medicinal formulae, and ritual protections that accumulated in the cycle over the centuries. Thus, the root tantra translated

21 For a preliminary study of Garuḍa medicine in Tibet, see Wayman 1987. For Garuḍa medicine in South Asia, see Slouber 2016. 
below represents the core of the Vase of Ambrosia cycle, which also went on to inspire further revelations by Rindzin Gödem (rig 'dzin rgod ldem, 13371408), Dorjé Lingpa (rdo rje gling pa, 1346-1405), Taksham Nüden Dorjé (stag sham nus ldan rdo rje, $1655^{-1708)}$ ), and other treasure revealers down to the eighteenth century. ${ }^{22}$ In recent years, instructions for ritual protection known as Vajra Armor or Dorje Gotrab, usually based on Dorjé Lingpa's work by the same name, have also gained popularity in English-speaking communities. ${ }^{23}$ Transcending barriers of time, space, and language, may the revealed teachings of Padmasambhava continue to protect sentient beings from the horrors of epidemic disease, even in our own degenerate age of the novel coronavirus.

\section{Translation of the Vase of Ambrosia: Root Tantra ${ }^{24}$}

\section{[Indian language: Amaraṇa-amrta-kalaśa-tantra]}

[Tibetan language: The Vase of the Deathless Ones' Ambrosia Tantra] ${ }^{25}$

22 See, respectively, Bdud rtsi bum chung (pp. 194-98), Rdo rje'i go khrab (pp. 262-70), and Phyugs kyi nad rigs bcos pa'i yig chung (pp. 331-38) in A ru ra 2006.

23 See, for example, Zopa 2011. Zopa Rinpoche authored this work and acknowledges neither the Vase of Ambrosia nor Dorjé Lingpa, further demonstrating the sectarian fluidity of this epidemiological cycle. By contrast, a Google search for Vajra Armor retreats in the year 2020 reveals more dedication to Padmasambhava and his treasure revelations.

24 This translation is based on four distinct editions of the Vase of Ambrosia: (1) and (2) two digital editions of manuscripts publicly shared by the Buddhist Digital Resource Center; (3) the aforementioned woodblock edition that is part of the Great Treasury of Precious Revelations; (4) a modern book edition of unclear provenance.

(1) BDRC1: Bdud rtsi bum chen ma bu cha lag tshang ma (Dpal spungs: Unpublished manuscript held at Pelpung monastery; BDRC \#W2PD17503), 176 folios; ff. 10a-17b translated below.

(2) BDRC2: 'Chi med bdud rtsi bum pa'i ma bu (Unpublished manuscript from a private collection, with the name Tsarong Lodrö Mingchen [tsha rong blo gros ming can] written on the back; BDRC \#W4CZ20873), 97 folios [incomplete]; ff. 2a-8a translated below.

(3) RCTD: Kong sprul blo gros mtha' yas, ed., 'Chi med bdud rtsi bum pa, in Rin chen gter mdzod chen mo (Paro and Delhi: Ngodrup and Sherab Drimay, 1976-80), vol. 46 (ha), pp. 445-691 (ff. 1a-124a); pp. 446-57 (ff. 1b-7a) translated below.

(4) ARR: A ru ra, ed., 'Chi med bdud rtsi bum pa, in Slob dpon pad 'byung gi sman yig gces btus, Bod kyi gso ba rig pa'i gna' dpe phyogs bsgrigs dpe tshogs, vol. 24 (Beijing: Mi rigs dpe skrun khang, 2006), 1-193; pp. 1-9 translated below.

My translation is primarily based on the two manuscript editions, with significant discrepancies between editions noted using [square brackets] and explained in the footnotes. I have also used [square brackets] to mark the translated chapter titles that usually appear at the end of each section.

25 These full Indian and Tibetan titles do not appear in BDRC2 (f. 2a), but they do appear in all other editions: BDRC1, f. 10a; RCTD 446 (f. 1b); ARR, 1. That being said, the Indian titles in BDRC1 and ARR read: $m a h[r]$ ina $[\mathrm{ma}]$ a mri ta ka la ha tan tra. 


\section{[Chap. 1. Introduction]}

To the Lama, the Tutelary Deity, the Precious Lord Physician, and the Victorious Sons, I pay homage. In the past, Lady Kharchenza Tsogyel posed several questions to Master Padmasambhava:

First, during this fortunate era, behaviors are good, the gods are indistinguishable from people, and the blessings of the compassionate and precious lords have not yet declined. During this time, malicious spirits and demons are bound by oath, and human beings reach the time of death without encountering the horrors of untimely [poisons]. ${ }^{26}$ In the future, will there be a degenerate age of poisonous disease and the miasma of malicious spirits and demons [from a previous age in Tibet], ${ }^{27}$ when [people] will have no freedom to practice the holy doctrine and their lives will come to untimely ends? Emaho! Great Master Padma! You, who are endowed with great clairvoyance, please tell me: During the degenerate age, will disease come to afflict beings without exception? Will peripheral peoples come to the center [of Tibet]? How long will the Buddhist teachings endure? When will this prophecy come to pass? Please tell me for the sake of posterity.

The Master was overcome by the compassionate motivation of these questions. Knowing that the time for training disciples had come, he replied:

Ema, Jomo Kharchenza! For sentient beings, from the trunk of ignorance the leaves of the five poisons and negative emotions spread, the harvest of the ten sins and nonvirtues grows, and the fruit of disease ripens. Three of every four [people] in the world will die. Turkic armies will come, and they will destroy the assembly of the teachings. ${ }^{28}$ Twenty-one portents will manifest, and virtue and sin will be performed indiscriminately. This is how the age of degeneration will come to pass.

The Lady offered a mandala of gold and turquoise to the Great Guru. She fed him with foods of the eight supreme flavors, and arranged offerings of immeasurable intricacy. She dressed him in silken clothing and warmly served her

26 BDRC2, 2b: "collapse" (rgyug ['gyel]). BDRC1, f. 1ob; RCTD, 447 (f. 2a); and ARR, 1: "poison" (gdug).

27 This short clause appears in neither BDRC2 (2b) nor ARR (1). BDRC1, 1ob; and RCTD, 447 (f. 2a): "lnga [= snga] bod la...."

28 BDRC1, 11a; and RCTD, 448 (f. 2b): "tu ru ka yi dmag dang 'byung / bstan pa'i tshong dus 'joms par byed/." BDRC2, 3a; and ARR, 2: "... but they will not destroy the assembly of the teachings" (bstan pa'i tshong dus bcom gyin med/). 
teacher. She then joined her hands together with a mind of reverence and, with fierce love and compassion, offered these words of supplication to his ear:

Ema, Great Guru! You know the three times clearly and without obstruction, and you know all human bodies without exception. For the various beings of the degenerate age, their supreme human incarnations that are difficult to find will meet untimely ends, and they will act perversely without the [Buddhist] doctrine. Because their skin and flesh will grow to be unbearable, please explain: what will the [2.] causes, [3.] conditions, and [4.] nomenclature [for this epidemic disease] be? What will its [5.] age, [6.] duration, [7.] protection, [8.] diagnosis, and [9.] treatment be? Please explain to me the medicinal compounds that will cure [this disease] without exception.

\section{[Chap. 2. The Causes of the Epidemic]}

[Padmasambhava] responded to the Lady's questions: Ema, Jomo Kharchenza! The beings of the degenerate age will behave according to vicious cycles of error. Lay ritual specialists will fail to keep their commitments, and monastic clerics will lapse in their vows and disciplinary codes. Lay people will lose their sense of shame and embarrassment, and monastic scholars will engage in pedantic disputes. Teachers will hoard and sell the holy doctrine, and yogis will senselessly flirt with their female students. Great meditators will secretly support wives and children, and religious teachers will turn their backs on the [Three] Jewels. By performing evil actions and perversions—-such as engaging with demons and [non-Buddhist] extremists, and offering live sacrifices to worldly gods and spirits—-their behavior will cause their own ruin.

\section{[Chap. 3. The Conditions of the Epidemic]}

Solitary demons, supreme stars, and royal spirits will grow angry, and the mother demons and mother spirits of the underworld will stir. Hala dogs and the other classes of gods and demons will grow agitated, ${ }^{29}$ and they will spread their poisonous miasma. Their pathogenic miasma will form into clouds, and disease, war, and famine will fall like rain. Skin diseases, swelling, and nyen spirit diseases will spread. People with bone diseases will be afflicted by a black skin disease. For people with blood diseases, [their blood] will swell and

29 The hala dog is a class of Earth Lords (sa bdag), and the name hala may refer to the poisonous being from the "Churning of the Ocean of Milk" myth, who is often called Halāhala or Kālakūța. Again, see Doniger 1975, 270-30o. "Dog poison” (khyi dug) is often a reference to rabies in the Tibetan tradition. 
collect into a pool. For people with flesh diseases, nyen spirits will turn the area around their hearts dark brown.

\section{[Chap. 4. The Nomenclature of the Epidemic]}

Nyen spirit disease, the final item of chapter three, rides on the horse of supporting winds. The fever will be [like] the inside of a thick robe, and it will manifest in the liver, the site of heat and bile. It is also called the "Yellow Chinese Spot," the "Black Collapse," the "Neck Bump Collapse," and the "Black Triad." The names for this illness are inexhaustible. Regarding these manifestations [of the disease], there is nothing that cannot be explained. If the [patient's] pulsations are quick, then the physician should treat the [patient's] bile. Only fools will treat their wind. Otherwise, if [the patient] has a bone disease, one should treat it as a cold disease. [One should mostly give instructions to the patient and make little contact with them $].{ }^{30}$

\section{[Chap. 5. The Age of the Epidemic]}

Within the span of sixty years, [long enough for] one's teeth to fall out, the heartless and murderous soldiers of peripheral peoples will seize this central country. When they conquer the lands of Tibet, a series of great disasters in the earth will occur. The bushes and trees will shake and sway, the mountains and boulders will fall into the valleys like rain, and all sentient beings will panic. After that, fires will blaze in the sky, and the brilliance of the sun, moon, and stars will wane. Rainfall will become [nonexistent] like a flower [growing in the sky] or the horn of a rabbit, causing the harvests of farming and herding to fail.

With a series of disasters in stone, [people] will no longer be able to grind [barley]. The roar of hot [poached barley] on a cold mill will wane. A disease called the "hunch" will also arise, causing people to have problems in their sense faculties and to lose their vitality. [People] will waste away like hungry ghosts, and emaciated bodies will stick to their seats. They will have no way to heal, and supreme medicines will become rare.

Regarding the behaviors and portents for these events, [people] will begin wearing the skins of wild dogs and hats made of yak hair. They will proclaim their lofty views and say the syllable phat without even knowing what it means. They will act perversely without the [Buddhist] doctrine and, when ages like this arise, the Black Collapse will spread.

30 BDRC2, 4b; RCTD, 451 (f. 4a); and ARR, 4: "phal cher kha dmar thogs pa nyung /." BDRC1 (13a) omits this advice to avoid touching a patient. 


\section{[Chap. 6. The Duration of the Epidemic]}

The skin disease will shift from community to community, like a beggar eating in town, for one month, one year, or even up to one [twelve-year] cycle. After contracting the disease, [the patient's skin] will fold like a Chinese woman's silken dress, or it will take on [the shape of] a small vase.

\section{[Chap. 7. Protection from the Epidemic]}

There are three kinds of methods for protecting against [the epidemic]: outer, inner, and secret. [7.1.] Outer protections include protective behaviors and rituals, [7.2.] inner protections include protective scouts and heroes, and [7.3.] secret protections include deity meditation and contemplations for protection.

[7.1.] Outer Protections: One should avoid conflicts, respect one's superiors, and perform the seasonal rituals in accordance with tradition. One should strive to fulfill one's duties, act with virtue, and recite the scriptures of the white [Buddhist] doctrine.

[7.2.] Inner Protections: The scouts should dwell inside, and the champions of the four borders should encircle and protect [the patient].

[7.3.] Secret Protections: From a state of nonconceptuality and emptiness, one should not separate from divine pride. One should imagine the emanation of a blue Garudia bird spirit in a mandala of blazing suns and moons.

\section{[Chap. 8. Diagnosis of the Epidemic]}

There are four types of disease: those that are caused by the four elements of fire, water, earth, and wind. There are three methods for examining disease: preliminary examination, the main examination, and the postexamination. In the preliminary examination, one should examine the types of elements. In the main examination, one should observe and examine [the patient's] viscera. Finally, one should examine whether [the patient] will live or die.

In accordance with the four elements, one should examine each of the gateways of entry, the pathways of wandering, the inhabited valleys, and the haunted castles. One should also examine each of the general and specific symptoms of particular diseases and spirits.

\section{[Chap. 9. Methods for Treating the Epidemic]}

There are three methods for treating [the epidemic disease]: treating the nyen spirit, the heat disease, and the wind disease. One should [9.1.] topple the mountains of the nyen spirits, [9.2.] extinguish fire skin and heat disease, and [9.3.] treat the wind and heal the body.

[9.1.] Toppling the Mountains of Nyen Spirits: [9.1.1.] After a royal spirit descends, one should use medicines to heal [the patient] in accordance with 
the scriptures. [9.1.2.] After diagnosing the disease type, one should draw out and extract [the disease]. [9.1.3.] After breaking the illusory body down into pieces, one should use a lancet to treat the site of descent [of the nyen spirit; that is, the bubo].

[9.1.1.] After a royal spirit descends, one should draw out [the disease] and cleanse [the site of descent on the patient]. One should employ the surgical repertoire of phlebotomy and cauterization, and then ask about the bodily constituents and [the basis of the disease]. ${ }^{31}$

[9.1.2.] After diagnosing the disease type, one should administer the antidote to the chest [of the patient] in accordance with the four elements of fire, water, earth, and wind. If [the patient] has a heat disease of the earth and fire [elements], then treat them with cooling [medicines]. If [the patient] has a cold disease of the water and wind [elements], then treat them with warming [medicines]. One should diagnose without wavering and one should strive to heal without error.

[9.1.3.] After breaking the illusory body down into pieces, one should use a lancet and medicines to treat the site of descent [of the nyen spirit; that is, the bubo]. From head to toe, elemental and thermal imbalances will arise. Specifically, if a painful lump appears, one should use an arrow of awareness, which is like the tools of a blacksmith, to pierce and treat it.

For the Black Triad, one should also generally use the great ambrosia compound to topple the nyen spirit mountains.

[9.2. Fire Skin and Heat Disease:] One should use cooling medicines and curative paste to extinguish fire skin and heat disease.

[9.3. Wind Disease:] One should use balanced nutrition to treat the wind and heal the body.

One should combine the [following] medicines together: three parts of the "great medicine" [black aconite] to counteract [the disease], great bitumen from a vast rockface, and water of special qualities. One should measure out doses of five, seven, nine, eleven, fifteen, and so forth, and prescribe [the medicine] in accordance with the contexts of the patient's constitution. If one does not think that [this compound] will heal the patient, one should prepare the Pomegranate-4 formula.

One should cherish and earnestly treat the young, the old, the infirm, and the abandoned like they are one's own heart. Free from conceptuality, endowed with the mind of enlightenment, for the sake of sentient beings as numerous

31 BDRC2, 6b; RCTD, 454 (f. 5b); and ARR, 7: "lus zungs nad kyi gzhi la dris/." BDRC1, 15b: "lus zungs nad dkyig zhi la dris/." 
as the sky, one should not separate from divine pride, and heal with love, compassion, and ferocity.

\section{[Chap. 10. Conclusion $]^{32}$}

Other than these treatments for the hot and cold aspects of the Black Collapse, alternative therapies cover the world like the sun. These medical teachings of the Vase of Ambrosia are extremely precious, however, like gold. They are superior to other [teachings], like the head [among the body parts], like the heart [among the viscera], and like the eyes among the sense organs. Like a jewel possessed by none other, if one has this [teaching], death will not arise. One should not share [this teaching] that is called the Vase of Ambrosia with anyone, and one should hold it within the vase of the mind. If one shares these eight branches of healing with others, their blessings will wane.

Even if punishments arise from the deakini goddesses and the protectors of the doctrine, even if one loses one's life, one should keep one's samaya commitments. One should value this trilogy of medicine and hold it as dearly as one's own heart. One should hold one's religious teacher as like one's own head, and keep one's commitments like one's own cherished eyes. From the Vase of Ambrosia, such are demonstrations of its greatness and analogies for cherishing it.

One should conceal this Vase of the Deathless Ones' Ambrosia in a place where it will not be transmitted. Then, when the age of degeneration has arisen, one should embrace strangers as if they were family, and [others] as if they were oneself. For the sake of their benefit, may other sentient beings encounter this text. I seal it with my body, speech, and mind, and, free from desire, conceal it as a treasure.

Thus spoke Master Padmasambhava. I, Jomo Kharchenza Tsogyel, arranged the contents and recorded them in writing. Thus ends the Vase of Ambrosia: Root Tantra. [It is also known as the Treatise of the Eight Branches, the Threefold Tantric Cycle, and the (Threefold Medical Cycle).] ${ }^{33}$

Samaya, seal, seal, seal, iti.

32 In вDRC1, 16b; and RCTD, 456 (f. 6b); chapter 9 ends and chapter 10 begins here. BDRC2, $7 \mathrm{a}-7 \mathrm{~b}$; and ARR, 8 both include the final paragraph of chapter 9 as the beginning of chapter 10 .

BDRC2, 8a; RCTD, 457 (f. 7a), and ARR, 9: "gzhung yan lag brgyad pa zhes kyang bya/ rgyud don skor gsum pa zhes kyang bya/ [gso dpyad don skor gsum pa] zhes kyang bya'o/." ARR (9) replaces the Threefold Medical Cycle with the Three Precious Heaps of Medicine (gso dpyad rin chen spung ba gsum pa). BDRC1 (17b) does not include any of these alternative titles. 


\section{About the Author}

William A. McGrath is the Robert H. N. Ho Family Foundation Assistant Professor of Buddhist Studies at New York University, where he teaches in the Department of Religious Studies. His research primarily concerns the historical intersections of religion and medicine in Tibet and China, and he recently published an edited volume entitled Knowledge and Context in Tibetan Medicine (Brill, 2019).

\section{Bibliography}

\section{Primary Sources}

A ru ra, ed. 2005. Cha lag bco brgyad. Bod kyi gso ba rig pa'i gna' dpe phyogs bsgrigs dpe tshogs, vol. 25. Beijing: Mi rigs dpe skrun khang.

A ru ra, ed. 2006. Slob dpon pad 'byung gi sman yig gces btus. Bod kyi gso ba rig pa'i gna' dpe phyogs bsgrigs dpe tshogs, vol. 24. Beijing: Mi rigs dpe skrun khang.

ARR: A ru ra, ed. 2006. 'Chi med bdud rtsi bum pa. In Slob dpon pad 'byung gi sman yig gces btus. Bod kyi gso ba rig pa'i gna' dpe phyogs bsgrigs dpe tshogs, vol. 24, pp. 1-193. Beijing: Mi rigs dpe skrun khang.

BDRC1: Bdud rtsi bum chen ma bu cha lag tshang ma. Dpal spungs: Unpublished manuscript, BDRC \#W2PD17503.

B DRC2: 'Chi med bdudrtsi bum pa'i ma bu. Private collection: Unpublished manuscript, BDRC \#W4CZ20873.

RCTD: Kong sprul blo gros mtha' yas, ed. 1976-80. 'Chi med bdud rtsi bum pa. In Rin chen gter mdzod chen mo, vol. 46 (ha), pp. 445-691 (ff. 1a-124a). Paro and Delhi: Ngodrup and Sherab Drimay.

\section{Secondary Sources}

Benedictow, Ole J. 2010. What Disease Was Plague? On the Controversy over the Microbiological Identity of Plague Epidemics of the Past. Leiden: Brill.

Doniger, Wendy. 1975. Hindu Myths: A Sourcebook Translated from the Sanskrit. New York: Penguin Books.

Dunnel, Ruth. 1994. "The Hsi Hsia." In Cambridge History of China, Vol. 6: Alien Regimes and Border States, 907-1368, edited by Herbert Franke and Denis Twitchett, 154-214. Cambridge: Cambridge University Press.

Green, Monica H. 200o. "The Four Black Deaths." American Historical Review 125, no. 5: 1601-31.

Green, Monica H. 2014. “Taking 'Pandemic' Seriously: Making the Black Death Global.” The Medieval Globe 1: 27-61. 
Gyatso, Janet. 2006. "A Partial Genealogy of the Lifestory of Ye shes mtsho rgyal." Journal of the International Association of Tibetan Studies 2: 1-27.

Gyatso, Janet. 2015. Being Human in a Buddhist World: An Intellectual History of Medicine in Early Modern Tibet. New York: Columbia University Press.

Hymes, Robert. 2014. "A Hypothesis on the East Asian Beginnings of the Yersinia pestis Polytomy." The Medieval Globe 1: 285-308.

Liang, Jue. 2020. "Conceiving the Mother of Tibet: The Life, Lives, and Afterlife of the Buddhist Saint Yeshe Tsogyel." PhD diss., University of Virginia.

McGrath, William A. 2017a. "Origin Narratives of the Tibetan Medical Tradition: History, Legend, and Myth." Asian Medicine 12, no. 1-2: 295-316.

McGrath, William A. 2017b. "Vessel Examination in the Medicine of the Moon King." In Buddhism and Medicine: An Anthology of Premodern Sources, edited by C. Pierce Salguero, 501-13. New York: Columbia University Press.

McGrath, William A. 2020. "Quarantine and Expulsion in Early Tibet: Reflections on the Padmasambhava Legend in the Age of the Coronavirus." Fieldsights (blog of the Society for Cultural Anthropology), "Hotspots" section, June 23, 2020. https:// culanth.org/fieldsights/quarantine-and-expulsion-in-early-tibet-reflections-on -the-padmasambhava-legend-in-the-age-of-the-coronavirus.

Parfionovitch, Yuri, Fernand Meyer, and Gyurme Dorje. 1992. Tibetan Medical Paintings: Illustrations to the Blue Beryl Treatise of Sangye Gyamtso (1635-1705). London: Serindia Publications.

Pasang Wangdu and Hildegard Diemberger. 2000. Dba' bzhed: The Royal Narrative Concerning the Bringing of the Buddha's Doctrine to Tibet. Vienna: Österreichischen Akademie der Wissenschaften.

Petech, Luciano. 199o. Central Tibet and the Mongols: The Yüan-Sa-skya Period of Tibetan History. Rome: Instituto Italiano per il Medio ed Estermo Oriente.

Rossabi, Morris. 1994. "The Reign of Khubilai Khan," In Cambridge History of China, Vol. 6: Alien Regimes and Border States, 907-1368, edited by Herbert Franke and Denis Twitchett, 414-89. Cambridge: Cambridge University Press.

Simioli, Carmen. 2019. "Knowledge, Imagery, and the Treatment of Communicable Disease in the Vase of the Amrta of Immortality: A Preliminary Analysis of a Nyingma Medical Corpus." In Knowledge and Context in Tibetan Medicine, edited by William A. McGrath, 218-6o. Leiden: Brill.

Slouber, Michael. 2016. Early Tantric Medicine: Snakebite, Mantras, and Healing in the Gāruda Tantras. Oxford: Oxford University Press.

Sperling, Elliot. 1987a. "Lama to the King of Hsia." Journal of the Tibet Society 7: 31-5o. Sperling, Elliot. 1987b. "Some Notes on the Early 'Brig-gung-pa Sgom-pa." In Silver on Lapis: Tibetan Literary Culture and History, edited by Christopher I. Beckwith, 33-53. Bloomington, IN: The Tibet Society. 
Sperling, Elliot. 2004. "Further Remarks Apropos of the 'Ba'-rom-pa and the Tanguts." Acta Orientalia Academiae Scientiarum Hungaricae 57, no. 1: 1-26.

Wayman, Alex. 1987. "Researches on Poison, Garuḍa-birds and Nāga-serpents Based on the Sgrub thabs kun btus." In Silver on Lapis: Tibetan Literary Culture and History, edited by Christopher I. Beckwith, 63-77. Bloomington, IN: The Tibet Society.

Wylie, Turrell V. 1977. "The First Mongol Conquest of Tibet Reinterpreted." Harvard Journal of Asiatic Studies 37, no. 1: 103-33.

Yang Ga. 2010. "Sources for the Writing of the Rgyud bzhi, Tibetan Medical Classic." PhD diss., Harvard University.

Zopa Rinpoche. 2011. Vajra Armor Protection Wheel. Translated by Fabrizio Pallotti (Champa Pelgye). Portland, OR: Foundation for the Preservation of the Mahayana Tradition. 